Artikel Penelitian

\title{
Hambat Ekstrak Etanol Rimpang Kunyit (Curcuma domestica V.) terhadap Pertumbuhan Bakteri Staphylococcus aureus Secara In Vitro
}

Putri Ramadhani ${ }^{1}$, Erly $^{2}$, Asterina $^{3}$

\begin{abstract}
Abstrak
Staphylococcus aureus merupakan salah satu bakteri patogen yang bisa menyebabkan infeksi. Penggunaan antibiotika untuk penanganan infeksi yang tidak rasional dapat membuat kuman patogen menjadi resistensi, sehingga penggunaan Rimpang kunyit (Curcuma domestica V.) mungkin dapat sebagai alternatif pengganti antibiotik. Tujuan penelitian ini adalah untuk mengetahui daya hambat ekstrak etanol rimpang kunyit (Curcuma domestica V.) terhadap pertumbuhan bakteri Staphylococcus aureus secara in vitro. Penelitian ini bersifat eksperimental laboratorium dengan desain post-test only control group design menggunakan metode difusi (cakram) yang dilakukan dari Februari 2015 sampai September 2015 di Laboratorium Mikrobiologi Fakultas Kedokteran Universitas Andalas. Sampel yang digunakan adalah rimpang kunyit yang berasal dari ladang kunyit Puncak Payo, Tanah Garam Solok. Berdasarkan hasil penelitian dapat disimpulkan bahwa ekstrak etanol rimpang kunyit (Curcuma domestica V.) memiliki daya hambat yang berbeda terhadap pertumbuhan bakteri S. aureus dengan berbagai konsentrasi yaitu 10\%, 20\%, 40\%, 80\% b/v . Konsentrasi ekstrak yang paling efektif dalam menghambat $S$. aureus adalah konsentrasi $80 \%$ b/v. Penggunaan ekstrak etanol rimpang kunyit (Curcuma domestica V.) sebagai alternatif pengganti antibiotik terhadap infeksi oleh $S$. aureus perlu dipertimbangkan.
\end{abstract}

Kata kunci: daya hambat, Curcuma domestica V, Staphylococcus aureus

\begin{abstract}
Staphylococcus aureus is one of pathogenic bacterium that can cause infection. Irrational use of antibiotics to treat infection can make the pathogen becomes resistance, resulting the failure of the treatment. Turmeric (Curcuma domestica V.) can be alternative of antibiotics. The objective of this study was to determine the inhibition of the ethanol extract of turmeric (Curcuma domestica V.) on the growth of Staphylococcus aureus in vitro. This study was an experimental laboratory with post-test only control group design that use diffusion method (discs) held from February 2015 to September 2015 in the Laboratory of Microbiology, Faculty of Medicine, University of Andalas. The sample used are turmeric from the fields of turmeric in Puncak Payo, Tanah Garam Solok. Based on the results of this study, it can be concluded that the ethanol extract of turmeric (Curcuma domestica V.) have different inhibition for the growth of S. aureus with various concentrations about 10\%, 20\%, 40\%, $80 \% \mathrm{w} / \mathrm{v}$. Concentration of the extract that most effective in inhibiting S. aureus is $80 \% \mathrm{w} / \mathrm{v}$. The use of ethanol extract of turmeric as an alternative of antibiotics must be considered
\end{abstract}

Keywords: inhibition, Curcuma domestica V, S.aureus

Affiliasi penulis: 1. Prodi Profesi Dokter FK Unand (Fakultas Kedokteran Universitas Andalas Padang), 2. Bagian Mikrobiologi FK Unand 3. Bagian Kimia FK Unand

Korespondensi: Putri Ramadhani ,Email : putridhani46@gmail.com ,Telp: 082388443917

\section{PENDAHULUAN}

Infeksi masih menjadi masalah kesehatan utama yang dihadapi negara maju dan berkembang, termasuk Indonesia. Berdasarkan Profil Kesehatan 
Indones9ia tahun 2010, penyakit infeksi bakteri merupakan penyakit dengan tingkat kematian tertinggi dan penyakit pertama dari 10 penyakit terbanyak yang dirawat di rumah sakit. Data Tabulasi Dasar (DTD) tahun 2010, pasien rawat jalan di rumah sakit Indonesia yang terbanyak juga pasien infeksi. Perbedaannya pada pasien rawat jalan, penyakit infeksinya adalah infeksi saluran nafas bagian atas sedangkan untuk rawat inap adalah diare dan gastroenteritis. ${ }^{1}$

Staphylococcus aureus (S. aureus) merupakan salah satu spesies dari genus Staphylococcus yang bersifat patogen utama bagi manusia. $S$. aureus bersifat koagulase positif yang membedakannya dengan spesies lain seperti Staphylococcus epidermidis (S. epidermidis) yang bersifat koagulase negatif yang merupakan flora normal pada manusia dan jarang menyebabkan infeksi. Hampir setiap orang akan mengalami beberapa jenis infeksi $S$. aureus sepanjang hidup, dengan kisaran keparahan dari infeksi kulit minor hingga infeksi berat yang mengancam jiwa. ${ }^{2}$ Infeksi oleh $S$. aureus ditandai dengan kerusakan jaringan yang disertai abses bernanah. Beberapa penyakit infeksi yang disebabkan oleh S. aureus adalah bisul, jerawat, impetigo dan infeksi luka. Infeksi yang lebih berat diantaranya pneumonia, mastitis, meningitis, infeksi saluran kemih, osteomielitis dan endokarditis. $S$. aureus juga merupakan penyebab utama infeksi nosokomial, keracunan makanan dan sindroma syok toksik.

Penyakit infeksi ini diatasi dengan menggunakan antibiotika. Penggunaan antibiotika yang tidak rasional seperti kepatuhan yang kurang pada masyarakat dapat membuat kuman patogen menjadi resisten. ${ }^{5}$ Munculnya mikroba resisten ini sebagai penyebab utama kegagalan pengobatan penyakit infeksi. $^{6}$ Diperlukan alternatif dalam mengatasi masalah ini dengan memanfaatkan bahanbahan aktif antimikroba dari tanaman obat.

Salah satu spesies dari Curcuma yang sering digunakan dalam pengobatan tradisional adalah Curcuma domestica V. atau yang biasa dikenal dengan kunyit. Kunyit telah digunakan dalam pengobatan tradisional selama berabad-abad di berbagai belahan dunia. Ada banyak negara di Asia
Selatan menggunakan kunyit sebagai antiseptik untuk luka bakar, memar dan antibakteri. Di Pakistan, kunyit digunakan sebagai agen anti-inflamasi dan obat untuk gangguan pencernaan, sedangkan di Afghanistan, kunyit digunakan untuk membersihkan luka dan merangsang pemulihan luka dengan meletakkan kunyit yang telah dibakar di atas luka. Sejak zaman kuno, kunyit telah digunakan untuk mengobati keseleo dan bengkak. Pada pengobatan Ayurvedic (India), kunyit digunakan sebagai pengobatan untuk berbagai gangguan pernapasan (seperti asma, hiperaktif bronkial dan alergi) serta untuk gangguan hati, anoreksia, rematik, luka diabetes, pilek, batuk dan sinusitis. ${ }^{7}$ Dalam pengobatan tradisional Cina, kunyit digunakan untuk mengobati penyakit yang berhubungan dengan nyeri perut. ${ }^{8}$

Kandungan utama Curcuma domestica V. adalah kurkuminoid dan minyak atsiri yang dapat berfungsi sebagai antimikroba (broad spectrum). Kurkuminoid dalam rimpang kunyit merupakan kelompok senyawa fenolik. Mekanisme kerja kurkumin sebagai antibakteri mirip persenyawaan fenol lainnya yaitu menghambat metabolisme bakteri dengan cara merusak membran sitoplasma dan mendenaturasi protein sel yang menyebabkan kebocoran nutrien dari sel sehingga sel bakteri mati atau terhambat pertumbuhannya. ${ }^{9}$ Aktivitas antibakteri pada kunyit juga dihubungkan dengan kandungan kimia utama dalam minyak atsiri. Komponen kimia dalam minyak atsiri terbagi dalam lima kelas pokok yaitu hidrokarbon monoterpen, monoterpen oksigenasi, hidrokarbon seskuiterpen, seskuiterpen oksigenasi dan lainnya seperti ester. ${ }^{10}$ Seskuiterpen dalam minyak atsiri kunyit merupakan turunan dari senyawa terpen yang dilaporkan memiliki aktivitas antibakteri yang kuat. ${ }^{11}$ Penelitian lainnya tentang aksi antimikroba oleh monoterpen menyebutkan bahwa terpen berdifusi ke dalam sel kemudian merusak struktur membran sel. ${ }^{12}$

Etanol merupakan salah satu pelarut yang dapat digunakan untuk mengikat semua zat aktif yang terkandung dalam rimpang kunyit karena bersifat netral, tidak beracun dan berabsorpsi baik. ${ }^{13,14}$

Pemberian ekstrak rimpang Curcuma domestica V. dalam berbagai konsentrasi yaitu $25 \%$, 
$50 \%, 75 \%$ dan $100 \%$ memiliki pengaruh terhadap bakteri E. coli. Hasil penelitian terlihat penurunan jumlah koloni seiring peningkatan konsentrasi. Secara keseluruhan terdapat perbedaan yang signifikan antara konsentrasi walaupun pada kelompok perlakuan $25 \%$ dan kelompok perlakuan $50 \%$ tidak terjadi perbedaan merata jumlah koloni bakteri $E$. coli yang signifikan. ${ }^{15}$ Hasil penelitian yang dilakukan secara in vitro, membuktikan bahwa senyawa aktif dalam rimpang Curcuma domestica V. mampu menghambat pertumbuhan bakteri Bacillus $s p$. dan Shigella dysentriae karena kunyit mengandung senyawa kurkuminoid dan minyak atsiri. ${ }^{16}$

\section{METODE}

Penelitian ini bersifat eksperimental dengan desain post-test only control group design. Penelitan dilakukan di Laboratorium Mikrobiologi Fakultas Kedokteran Universitas Andalas pada bulan Februari 2015 hingga Oktober 2015. Populasi adalah rimpang kunyit (Curcuma domestica V.). Sampel adalah rimpang kunyit yang ditanam di ladang kunyit Puncak Payo, Tanah Garam Solok. Sampel diambil dengan menggunakan metode purpose sampling yaitu metode pemilihan sampel dengan cara memilih sampelsampel tertentu yang memenuhi kriteria inklusi. Kriteria inklusi adalah umbi utama rimpang Curcuma domestica $\mathrm{V}$., berdiameter $\pm 1-2 \mathrm{~cm}$, panjang $\pm 5-15$ $\mathrm{cm}$, warna kulit luar coklat terang, bagian dalam berwarna jingga, ada sedikit serabut. Kriteria eklusi adalah terpapar sinar matahari, berkerut dan kering. Independen Variabel bebas adalah ekstrak rimpang Curcuma domestica V. Variabel tergantung adalah pertumbuhan bakteri $S$. aureus. Bahan yang digunakan pada penelitian ini adalah: Ekstrak rimpang kunyit (Curcuma domestica V.), bakteri murni Staphylococcus aureus, agar Mueller Hinton II, aquades steril, $\mathrm{NaCl}$ 0,9\%, alkohol $70 \%$, etanol $96 \%$. Alat yang digunakan dalam penelitian ini adalah: cawan petri, tabung reaksi, kertas saring, pelubang kertas, lem, jarum ose, lampu spritus, pinset, gelas ukur, autoklaf, inkubator, spuit disspossible, lidi kapas steril, mistar, pisau, talenan. Data diolah secara statistik untuk menganalisis daya hambat ekstrak etanol rimpang Curcuma domestica V. terhadap pertumbuhan bakteri $S$. aureus dengan metode Anova satu arah dengan derajat kepercayaan $95 \%(=0,05)$ dan bila di dapat perbedaan nyata antar perlakuan maka akan dilakukan dengan Post Hoc Test dengan taraf kesalahan $1 \%$.

\section{HASIL}

Tabel 1. Hasil uji sensitivitas $S$. aureus dengan menggunakan kontrol positif, ekstrak etanol Curcuma domestica V. dan kontrol negatif

\begin{tabular}{|c|c|c|c|c|c|}
\hline \multirow[t]{2}{*}{ Perlakuan } & \multicolumn{4}{|c|}{ Pengulangan } & \multirow{2}{*}{$\begin{array}{c}\text { Diameter } \\
\text { rata-rata } \\
(\mathrm{mm})\end{array}$} \\
\hline & I & II & III & IV & \\
\hline I (etanol) & 0 & 0 & 0 & 0 & 0 \\
\hline II $(10 \% \mathrm{~b} / \mathrm{v})$ & 10 & 8 & 7 & 8 & 8,25 \\
\hline III $(20 \%$ b/v $)$ & 10 & 13 & 12 & 11 & 11,5 \\
\hline IV $(40 \%$ b/v $)$ & 8 & 7 & 12 & 8 & 8,75 \\
\hline $\mathrm{V}(80 \% \mathrm{~b} / \mathrm{v})$ & 14 & 15 & 14 & 14 & 14,25 \\
\hline VI (amoksisilin) & 35 & 23 & 24 & 24 & 26,5 \\
\hline
\end{tabular}

Berdasarkan penelitian yang telah dilakukan, didapatkan bahwa ekstrak etanol rimpang Curcuma domestica $\mathrm{V}$. dengan konsentrasi yang berbeda memiliki daya hambat yang berbeda terhadap pertumbuhan bakteri $S$. aureus. Perbedaan ini selanjutnya diuji dengan pengukuran statistik secara komputerisasi menggunakan uji Annova satu arah. Berhubung data penelitian yang didapatkan ternyata tidak memenuhi syarat uji Annova satu arah maka untuk melakukan pengolahan data dilanjutkan dengan uji Kruskall Wallis.

Hasil uji statistik didapatkan nilai $p=0,001$ $(p<0,05)$ yang berarti bahwa terdapat perbedaan yang bermakna antara konsentrasi yang diberikan, kontrol negatif dan kontrol positif dengan daerah bebas bakteri yang dihasilkan, sehingga pengolahan data dilanjutkan dengan Mann-Whitney Test. 
Tabel 2. Hasil uji Mann Whitney terhadap S. aureus

\begin{tabular}{|c|c|c|}
\hline \multicolumn{2}{|c|}{ Perlakuan } & \multirow{2}{*}{$\begin{array}{c}\mathbf{p} \\
0,013\end{array}$} \\
\hline I (etanol) & II $(10 \% \mathrm{~b} / \mathrm{v})$ & \\
\hline & III $(20 \% \mathrm{~b} / \mathrm{v})$ & 0,014 \\
\hline & IV $(40 \% \mathrm{~b} / \mathrm{v})$ & 0,013 \\
\hline & $\mathrm{V}(80 \% \mathrm{~b} / \mathrm{v})$ & 0,011 \\
\hline & VI (amoksisilin) & 0,013 \\
\hline \multirow[t]{4}{*}{ II $(10 \%$ b/v $)$} & III $(20 \%$ b/v $)$ & 0,028 \\
\hline & IV $(40 \% \mathrm{~b} / \mathrm{v})$ & 0,877 \\
\hline & $\mathrm{V}(80 \% \mathrm{~b} / \mathrm{v})$ & 0,017 \\
\hline & VI (amoksisilin) & 0,019 \\
\hline \multirow[t]{3}{*}{ III $(20 \%$ b/v $)$} & IV $(40 \% \mathrm{~b} / \mathrm{v})$ & 0,108 \\
\hline & $\mathrm{V}(80 \% \mathrm{~b} / \mathrm{v})$ & 0,018 \\
\hline & VI (amoksisilin) & 0,020 \\
\hline \multirow[t]{2}{*}{ IV $(40 \% \mathrm{~b} / \mathrm{v})$} & $V(80 \% \mathrm{~b} / \mathrm{v})$ & 0,017 \\
\hline & VI (amoksisilin) & 0,019 \\
\hline $\mathrm{V}(80 \% \mathrm{~b} / \mathrm{v})$ & VI (amoksisilin) & 0,017 \\
\hline
\end{tabular}

Berdasarkan Tabel 2 hasil yang didapatkan adalah ada perbedaan yang bermakna pada setiap perlakuan $(p<0,05)$. Tetapi tidak terdapat perbedaan bermakna antara perlakuan II $(10 \% \mathrm{~b} / \mathrm{v})$ dengan perlakuan IV ( $40 \% b / v)$ karena $p=0,877(p>0,05)$. Terlihat juga bahwa tidak terdapatnya perbedaan antara perlakuan III $(20 \% \mathrm{~b} / \mathrm{v})$ dengan perlakuan IV $(40 \% b / v)$ karena $p=0,108(p>0,05)$.

\section{PEMBAHASAN}

Penelitian uji daya hambat ekstrak etanol rimpang kunyit (Curcuma domestica V.) terhadap pertumbuhan $S$. aureus menunjukkan bahwa ekstrak rimpang (Curcuma domestica V.) dengan konsentrasi $10 \%$ b/v, 20\% b/v, 40\% b/v, $80 \%$ b/v dapat menghambat pertumbuhan bakteri tersebut. Hal ini menunjukkan adanya senyawa aktif dalam ekstrak rimpang Curcuma domestica V. yang diduga diperoleh dari kandungan kimia yang terdapat didalamnya yaitu kurkumin yang mengandung gugus hidroksil fenolat dan minyak atsiri yang mengandung senyawa terpen mirip alcohol. ${ }^{17}$
Kemampuan bakterisidal dari fenol dan senyawa terpen dengan mendenaturasikan protein dan merusak membran sitoplasma sel. Ketidakstabilan pada dinding sel dan membran sitoplasma bakteri menyebabkan fungsi permeabilitas selektif, fungsi pengangkutan aktif, pengendalian susunan protein sel bakteri terganggu. Gangguan integritas sitoplasma berakibat pada lolosnya makromolekul dan ion dari sel. Sel bakteri kehilangan bentuknya sehingga lisis. Persenyawaan fenolat bersifat bakteriostatik tergantung dari konsentrasinya. ${ }^{18}$

Pengukuran zona hambat pertumbuhan bakteri mendapatkan rerata diameter daerah bebas kuman yang paling kuat adalah ekstrak etanol rimpang (Curcuma domestica V.) dengan konsentrasi $80 \% \mathrm{~b} / \mathrm{v}$. $\mathrm{Hal}$ ini disebabkan karena pada konsentrasi $80 \% \mathrm{~b} / \mathrm{v}$ kandungan ekstrak lebih banyak sehingga kadar konsentrasi kurkumin dan minyak atsiri juga lebih besar. Namun, perbedaan efek antibakteri antara ekstrak etanol rimpang $10 \% \mathrm{~b} / \mathrm{v}$ dan $20 \% \mathrm{~b} / \mathrm{v}$ dengan konsentrasi $40 \%$ b/v tidak bermakna secara statistik karena $p>0,05$. Hal ini mungkin disebabkan karena larutan tidak homogen atau jumlah ekstrak kunyit yang akan dilarutkan tidak sesuai berat seharusnya.

Hasil penelitian ini memiliki kesamaan dengan penelitan yang dilakukan oleh Niamsa (2009) tentang aktivitas antimikroba Curcuma longa (turmeric) dalam ekstrak aquos. Curcuma longa dalam ekstrak aquos menunjukkan aktivitas antimikroba terhadap E. coli, S. aureus, K. pneumoniae and S. epidermidis. Walaupun beberapa kandungan kimia dalam kunyit tidak terlarut seluruhnya karena sifat kepolaran yang berbeda seperti minyak atsiri bersifat nonpolar dan air bersifat polar. $^{19}$

Penelitian yang dilakukan oleh Gupta et al pada tahun 2015 tentang evaluasi aktivitas antimikroba ekstrak rimpang Curcuma longa (turmeric) terhadap S. aureus menunjukkan terdapat efek daya hambat ekstrak Curcuma longa dalam berbagai fraksi berbeda seperti petroleum eter, kloroform, benzena dan metanol dengan bubuk Curcuma longa diperoleh dari pasaran. $^{20}$

Penelitian ekstrak rimpang kunyit (Curcuma domestica V.) dalam berbagai konsentrasi terhadap 
bakteri lain seperti E.coli juga telah dilakukan oleh Deffy (2009). Hasil penelitiannya menunjukkan bahwa dengan konsentrasi 25\%, 50\%, $75 \%$ dan $100 \%$ berpengaruh dalam menghambat jumlah pertumbuhan bakteri E.coli secara in vitro. ${ }^{15}$

\section{SIMPULAN}

Ekstrak etanol rimpang Curcuma domestica V. memiliki daya hambat terhadap pertumbuhan bakteri S. aureus. Ekstrak etanol rimpang Curcuma domestica V. dalam berbagai konsentrasi $10 \% \mathrm{~b} / \mathrm{v}, 20 \% \mathrm{~b} / \mathrm{v}, 40 \%$ $\mathrm{b} / \mathrm{v} 80 \% \mathrm{~b} / \mathrm{v}$ memiliki daya hambat yang berbeda terhadap pertumbuhan bakteri $S$. aureus. Konsentrasi yang memiliki diameter daya hambat tertinggi adalah konsentrasi $80 \%$ b/v.

\section{UCAPAN TERIMA KASIH}

Terima kasih kepada Analis Laboratorium BIOTA Sumatera Unand dan segenap staff Mikrobiologi FK Unand yang telah membantu terlaksananya penelitian ini.

\section{DAFTAR PUSTAKA}

1. Kementrian Kesehatan Republik Indonesia. Profil Kesehatan Indonesia tahun 2010. Jakarta: Kementrian Kesehatan RI; 2011.

2. Jawetz, E, Melnick JL, Adelberg EA. Mikrobiologi kedokteran (terjemahan). Edisi ke-25. Jakarta: EGC; 2010.

3. Ryan KJ, et al. Staphylococci In Medical microbiology : an introduction to infectious disease. Edisi ke-5. Amerika Serikat: Mc GrawHill; 2011.

4. Warsa UC. Staphylococcus. Dalam: Buku ajar mikrobiologi kedokteran. Edisi Revisi. Jakarta: Binarupa Aksara; 2010.

5. Refdanita, et al. Pola kepekaan kuman terhadap antibiotik di ruang rawat intensif rumah sakit Fatmawati Jakarta. Majalah Kesehatan. 2004;8(2): 41-8.

6. Ibrahim TA, et al. Antibacterial activity of herbal extracts against multi drug resistent strain of bacteria. Clinical Original Life Science. 2011;480-8

7. Araujo C, Leon L. Biological activities of curcuma longa linn. Memorias do Instituto Oswaldo Croz 96. 2001:723-8.
8. Aggarwal B. et al. From Traditional ayurverdic medicine to modern medicine : identification of therapheutic targets for suppresion of inflammation and cancer. Expert Opinion on Therathogenic Targets 10. 2006:87-118.

9. Madigan M. Broch biology of microorganisme. London: Prentice-Hall; 2005.

10. Imelouane $\mathrm{B}$, et al. Chemical composition and antimocrobial activity essential oil of thyme (Thymus Vulgaris). Eastern Marocco International Jurnal AgroBiology 11. 2008:2005-8.

11. Sashidaran, Menon AN. Comparative chemical composition and antimicrobial activity fresh and dry gingger oil (Zingiber officinale Roscoe). International Jornal Current Pharmacy research 2. 2010:40-3.

12. Matasyoh LG, et al. Chemical composition and antimocrobial activity essential oil of Ocimum grattisium I. growing in Eastern Kenya Afrika. Journal Biotechnology. 2007;6(6):760-5.

13. Kurniati W. Kajian aktivitas ekstrak etanol rimpang kunyit (Curcuma domestica Vallin) dalam proses penyembuhan luka pada mencit (Mus musculus Albinus) (skripsi). Bogor: Institut Pertanian Bogor; 2008.

14. Kusumadewi NK. Pengaruh ekstrak rimpang kunyit (Curcuma domestica Val) metode maserasi dan dekok terhadap penurunan suhu tubuh tikus putih (Rattu Norvegicus) yang diberi vaksin DPT (skripsi). Denpasar: Universitas Udayana; 2014.

15. Deffy L. Pengaruh pemberian ekstrak rimpang kunyit (Curcuma domestica Val) terhadap pertumbuhan Escherichia coli secara in vitro (skripsi). Semarang: Universitas Islam Sultan Agung; 2010.

16. Warnaini C. Uji Efektifitas ekstrak kunyit sebagai antibakteri terhadap pertumbuhan bakteri Bacillus Sp. dan Shigella dysentriae secara invitro (skripsi). Bandung: Universitas Padjajaran; 2009.

17. Sinaga S, Sihombing DTH, Kartiarso, Bintang M. Pengaruh pemberian tepung kunyit (Curcuma domestica val) sebagai pengganti antibiotik sintetis dalam ransum babi jantan kastrasi periode grower (skripsi). Bandung: Fakultas Peternakan Universitas Padjadjaran; 2009. 
18. Pelczar MJ, Chan ECS. Dasar- dasar mikrobiologi. Jilid 2. Jakarta: Universitas Indonesia Press; 2006.

19. Niamsa N. Antimicrobial activity of Curcuma longa aquos extract. Journal of Pharmacological Toxicology. 2009;4:173-7.
20. Gupta A, et al. Evaluation Of antimicrobial activity of Curcuma longa rhizome extract agains Staphylococcus aureus. Biotechnology Report Elseviere. 2015;(6):51-5. 